CLINICAL HEMORHEOLOGY, Vol. 8, pp. 7-12, 1988

$0271-5198 / 88 \$ 3.00+.00$ Printed in the USA.

Copyright (c) 1988 Pergamon Journals Ltd. All rights reserved.

\title{
A TRIBUTE
}

TO ROBERT MAXWELL

FOUNDER AND PUBLISHER OF PERGAMON PRESS

On behalf of the entire Editorial Board of this Journal I congratulate Robert Maxwell on the occasions of his sixty-fifth birthday on 10 June 1988 and the Fortieth Anniversary of Pergamon Press in 1988. It makes me particularly happy to accept Dr. Elisabeth Maxwell's gracious invitation to contribute, in a personal way, to the Festschrift in honor of her husband, my dear friend Bob.

I had not then known Bob when in the early part of 1959 I received a phone call from him. At that time I had already been in London for two years, where I had the positions as Head of the Medical Research Laboratories of Charing Cross Hospital and Director of Experimental Research in Vascular Diseases. Bob's phone call surprised me greatly. He said that he had heard that I belonged to the Organizing Committee of the Conference "Flow Properties of Blood and Other Biological systems", to be held at the University Laboratory of Physiology in oxford on 23 and 24 september 1959, convened jointly by the Faraday Society and the British Society of Rheology.

Bob told me that a volume of the Proceedings of the Conference was being planned and that our Committee was in negotiations with Academic Press regarding its publication. He emphasized that Pergamon Press could offer better conditions than Academic Press. I only could answer that the negotiations regarding the publication of the Conference Proceedings, conducted by Prof. R.G. Macfarlane, FRS of the Radcliffe Infirmary, Oxford, might already be concluded. 
Bob replied that he was certain that they were not, and would, therefore, appreciate it, if I would bring the conditions of Pergamon Press to the attention of the Organizing Committee. I said that, since the next meeting was to be the following day at the Radcliffe Infirmary, he might not have sufficient time to prepare a written proposal. He responded that I should expect to receive the conditions of Pergamon Press by messenger later in the day and would merely ask me to have them read to the Committee the next day. I assured Bob that I could do so, but could not promise anything beyond this. As the conditions were by far more favorable, the Committee, including Prof. Macfarlane, decided to accept them and informed Pergamon Press accordingly.

While I edited the Proceedings, I received the second phone call from Bob, without ever having met him, in October 1959. He told me that he heard most favorable comments about the success of our Conference in oxford and the high scientific merit of its communications. Bob invited me to visit with him in his London office at Fitzroy Square, as he wanted to start an international journal of biorheology and asked me to be its Editor-in-Chief. I suggested to bring along my friend Dr. George scott Blair, who headed the Physics Department of the National Institute for Research in Dairying at Shinfield, near Reading. I wanted George to be a Co-Editorin-Chief, in case the journal could be realized. Bob agreed and we then met in his office about a week later. At that meeting, both George and I tried to caution Bob about this venture and emphasized that an earlier American journal of rheology did not survive. He commented that whoever published the journal apparently did not know how to go about it. Bob stressed that he anticipated to lose money for about the first five years. Only after this time would he expect Pergamon Press to break even and only after some additional time would he hope to make a profit. So encouraged we decided to go ahead. The name we chose was BIORHEOLOGY, AN INTERNATIONAL JOURNAL, and publication began in 1962 .

The journal BIORHEOLOGY was indeed, financially, not a success for a long time. Nevertheless Bob maintained its publication, because he sensed its scientific importance. The journal has had a 
great impact in the development of the new science of biorheology. This is also demonstrated by the establishmen't of the first Chair of Biorheology at the Weizmann Institute of Science, Rehovot, Israel. It was given in 1981 to Professor Alex Silberberg, who had become Co-Editor-in-Chief in 1980 after Dr. Scott Blair's resignation in 1978 due to his failing eyesight.

Bob impressed me greatly by the audacity of his way of thinking. When the journal was started,it was merely eleven years after I had introduced the term 'biorheology' for the life science, which comprises the study of deformation behavior including flow of materials, in a biological context, of significance in life processes. Today, of course, the science of biorheology is considered to be the missing link between most, if not all, life sciences. What I admired in Bob, from our first meeting in 1959, was his recognition of the significance of this new science, his readiness to risk money on it, and the enthusiasm he showed as a publisher for a scientific discipline which at that time was known only to the very few who practiced it.

Ever since I first made the personal acquaintance of Bob, I thought of him as a leader among publishers and as a daring nonscientist with exceptional insight into the future of science. I am glad to say that in several publications and in Plenary Lectures of several International Congresses, I have been able to express my gratitude and that of my fellow scientists to Bob for the role he played in advancing the science of biorheology.

In my experiences as an editor of a number of publications, Bob's leadership fundamentally affected also the furtherance of biomedical science, in which I have been involved for about half a century. My studies relate to what I consider an entity, namely, the circulating blood and vessel wall which I conceive as a unique organ, named "vessel-blood organ", penetrating all other organs. It concerns a branch of biorheology, which I named "hemorheology" in 1951. Thus it deals with the physiology and pathology of blood circulation as well as with exchanges between the blood and the tissues. 


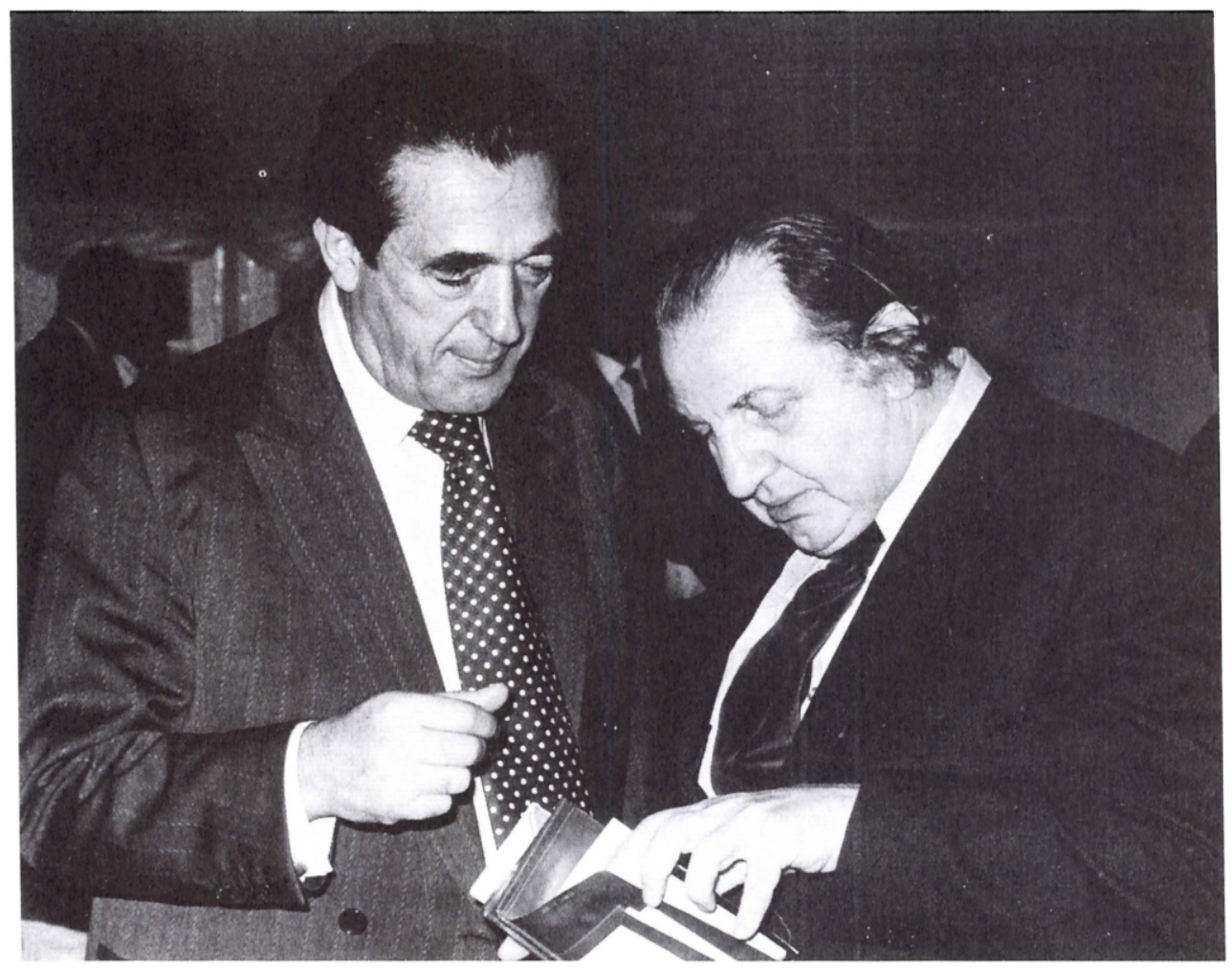

Robert Maxwell (left) and Alfred L. Copley (right), looking for a photograph, during a festivity of Pergamon press on 18 October 1975 at Headington Hill Hall, Oxford, England.

Among the disease processes of the vessel-blood organ are thrombotic and hemorrhagic conditions, which are the main cause of death in the Western world. Many years ago, I interested Bob in the publication of a medical research journal, named THROMBOSIS RESEARCH - AN INTERNATIONAL JOURNAL OF VASCULAR OBSTRUCTION, HEMORR-HAGE AND HEMOSTASIS. This happened on Bob's visit to New York in 1971 at a meeting which we had in his suite at the Pierre Hotel. often I am reminded of this journal's foundation, when, from my home at 50 Central Park West, I am looking out the window facing the hotel on Fifth Avenue across Central Park, which is 'my garden' The journal first appeared bimonthly in 1972 and since 1980 is published twice each month. Many readers consider it the leading journal in these fields. 
Bob agreed to have as Co-Editor-in-Chief of THROMBOSIS RESEARCH Professor Birger Blombäck of the Karolinska Institute, Stockholm and the New York Blood Center, New York. We also agreed to have, for the sake of rapid publication, forty-eight editors in different parts of the globe. He accepted my proposal that, for the same reason, it be printed from photocopy and that each editor take the responsibility for the acceptance of a contribution and this to be noted on its title page. This new approach in publishing a scientific journal was approved by Bob without hesitation. It was later also applied to BIORHEOLOGY and to the new journal CLINICAL HEMORHEOLOGY, which I initiated.

CLINICAL HEMORHEOLOGY, A Companion Journal of BIORHEOLOGY, arose because a marked increase of original contributions in the field of clinical hemorheology, as submitted to our journal BIORHEOLOGY, would have made it mainly a medical journal. Moreover, the growing number of communications in clinical hemorheology necessitated an international journal of clinical investigation to serve as an aid in the practice of medicine in all its fields. Bob saw the significance in acquainting physicians and surgeons with clinical hemorheology and to advance diagnostic, therapeutic and prophylactic hemorheological approaches towards better medical care. The journal CLINICAL HEMORHEOLOGY thus began publication in 1981 with Professor Siegfried Witte of the Diakonissen-Krankenhaus, Karlsruhe and the Medical Faculty of the University of Freiburg, Freiburg im Breisgau, F.R. Germany and myself as Co-Editors-inChief. Both BIORHEOLOGY and CLINICAL HEMORHEOLOGY became the official journals of the International Society of Biorheology.

I like to re-emphasize that what I always admired in Bob was his open mind and his keen interest in new ideas. This is also manifested by Bob's acceptance of my proposal to have on the front cover of a scientific journal a drawing of mine which would appear on each subsequent issue. In this way, the identity of the journal is recognized immediately. This was introduced in 1962 with the first issue of BIORHEOLOGY. Later it was implemented again with the journals THROMBOSIS RESEARCH and CLINICAL HEMORHEOLOGY and also 
with another Pergamon Journal, ACUPUNCTURE \& ELECTRO-THERAPEUTICS RESEARCH, of which I am the Co-Founder. Meanwhile, the practice of having a picture on the front cover as identification for a journal has been accepted by many other publishers, but it was Bob who pioneered it.

Alex Silberberg, Birger Blombäck and Siegfried Witte as well as every one of the Editors of BIORHEOLOGY, THROMBOSIS RESEARCH and CLINICAL HEMORHEOLOGY join me in sending our Best wishes and Warmest Birthday Greetings to Robert Maxwell.

Al Copley

50 Central Park West

New York, New York 10023

Polytechnic University

Brooklyn, New York 11201 